\title{
International Youth Theatre Festival at Volksbühne, Rosa-Luxemburg-Platz, Berlin
}

\author{
The Goethe Institute promotes German theatrical work with \\ young learners from Europe
}

Friedhelm Roth-Lange

\section{About traversing political and linguistic barriers}

A dense wall of black bodies is moving across the dimly lit stage. Three faces appear and disappear between the heads and feet of the human chain. They belong to a pregnant woman, her husband and their daughter. They try to find a loophole in this chain to make the breakthrough, sometimes by strategic moves, sometimes by force. Although the intruders eventually succeed and find a provisional place to live, the battle is still on. While looking for an apartment and a job, they are confronted with ever-changing forms of discrimination and xenophobia.

Impressive and space-filling images by Dolný Kubin's Slovakian pupils depict the experience of a family emigrating to an unknown country and who, after having traversed the border, are soon faced with tricky German language barriers: a soup doesn' $t$ "stink", it rather "smells."

What is special about this performance is its very strong imagery and spirited acting, strikingly stimulated by special settings. For example, a large, sliced-open box that serves as an emergency shelter for the refugees. The intuition of the actors for minimalist linguistic jokes („ein Gehweg ist kein Stehweg“11) and their courageous associative narration is also remarkable in this play.

The students from Rennes are quite determined to avoid a linear development of the drama. Instead, the members of the agile and well-trained company become the protagonist and emit scenic sparks from of a diverse mixture of literary miniatures and spirited choreographies with a focus on exclusion and discrimination of the Other.

Both of these productions are particularly good examples of the quality of theatre projects at the International Youth Theatre Festival from $5^{\text {th }}$ to $8^{\text {th }}$ of June, 2014 at the Volksbühne in Berlin.

\footnotetext{
1 "A pedestrian walkway is no place to stand around."
} 


\section{Heroic scenes from the daily crises in Europe}

Ten groups of pupils from Spain, Portugal, France, Lithuania, Poland, Slovakia and Germany developed under the slogan „Helden - ich und die anderen “2 ${ }^{2}$ their own thirty-minute plays in German, which were performed to a multilingual audience in the „3. Stock“, the acting room of the youth club at the Volksbühne. To the female protagonist in "Ella", heroes only exist in the media. She desperately but unsuccessfully longs for them, as the exclusion from her classmates drives her close to suicide (IES Miramar from Barcelona). Heroes are youths who courageously intervene when witnessing a fight or a neighbour's eviction from her apartment (IES Garcilaso de la Vega from Andalusia). Furthermore, heroes are prominent Romani People like the boxer Rukeli Trollman, whose German championship title was taken away by the Nazis and who was eventually battered to death by a warden at the concentration camp in Neuengamme in 1944 (Romani drama group from Berlin). Heroes are also the Polish friends of a girl who throws a tomato straight into the face of the President (Gymnasium Stadniska Wola). As sub-heroes of the diverse multicultural scene of the capital Berlin, eleven members of StreetUniverCity finally appear in a provocative performance which is staged as invisible theatre among the audience.

\section{Searching for heroes in the workshop offer}

Various workshops were offered to the festival participants in the mornings: the interfaces between film and theatre were investigated with hand-held cameras, and drafts for a video clip were developed ("Reclam goes Celluloid"). With the help of experienced gamers from Machina Ex, formats for interactive theatrical games were being tested. The participants handcrafted their superheroes à la Helmi, a theatre company famous for their trashy dolls made from rubber foam, or they translated tearful and melodramatic stories into almost wordless sketches, using cooking utensils, box boards and other paraphernalia ("To look for heroes where they are not"). The Australian singer Dyko rehearsed German variations of David Bowie's song "Heroes" from 1973 composed by groups of the countries participating in the festival. The peak of the presentation on the stage was the performance of an extract of Kurt Weill's opera „Der Jasager und der Neinsager": Under the guidance of director Andreas Merz-Raykov, the artistic directors of the participating groups showed how to stage a thrilling performance with choral chant and movement in the middle of a scenery of two dozen plastic chairs. The only point of regret is that, due to the dense schedule of the festival, there was no time for a critical exchange about the performances.

\footnotetext{
2 "Heroes - Me and the Others."
} 


\section{Theatre education for language teachers}

This festival is part of the successful language programme reorientation of the Goethe Institute. Based on new impulses from Madrid, Barcelona and Turin, the integration of theatrical work into language teaching has gained centre stage. Creative acting and reacting can be seen as one of the most important potentials in a holistic and action-oriented understanding of foreign language learning. Language teaching which includes theatre is not only great fun, it also motivates through authenticity which results in better outcomes. With this pedagogical expansion of its language programme, the Goethe Institute answers to increasing demands for a performance-oriented foreign language education. 'Aesthetic learning' was the key issue at the DaF-conference at Universidad Nacional Autónoma de México in 2013. In her very important study "Foreign language teaching and neuroscience", Michaela Sambanis (2013) has recently assembled compelling reasons for the inclusion of drama and theatre methods and for the use of performative techniques for teaching and learning foreign languages. ${ }^{3}$

An important partner of the local Goethe Institute at this festival was the initiative "Schulen - Partner der Zukunft." ${ }^{4}$ The underlying rationale is to offer language students a platform where they can exchange their original theatre productions, get to know peers with a different cultural background at theatre workshops, and use the German language in an action-oriented and real context.

For the first time the department of education will offer an one-week summer school at Goethe Institute in Madrid as a continuing education course for teachers. At the theatre Clave in Catalonia there will be the opportunity to get to know all facets of theatrical work under the guidance of competent practitioners. The climax of this week is supposed to be the performance of a musical which will be developed by participants and workshop instructors alike.

An emphatic word of warning though: an exclusive instrumental understanding of theatrical plays as vehicles for the improvement of everyday communication and expressions or idioms falls short of meaningful and aesthetic foreign language education. Michael Höfig, a notorious instigator of theatrical work with young learners of German at the Goethe Institute Madrid, is the art director of the festival at Volksbühne in Berlin along with Vanessa Unzula Troya. He emphasizes that working on theatrical performances with young people who are learning about German theatre as an artistic experience needs to be taken seriously and should keep its intrinsic aesthetic value: "When the young people get into the flow of appreciative acting, language development unfolds automatically."

The editors of Scenario and the editors of the Zeitschrift für Theaterpädagogik aim to promote intercultural dialogue in the area of drama and theatre

\footnotetext{
3 "Fremdsprachenunterricht und Neurowissenschaften", Tübingen: 2003, Narr Verlag.

4 "Schools - Partners of the Future."
} 
pedagogy through closer collaboration between the two journals, including the parallel publication of articles. Please note that this article is a translation of the German language version to be published this year in the Zeitschrift für Theaterpädagogik. Translators: Sophia Frank/Susanne Even 